\title{
Mark-ups in the Hungarian Corporate Sector
}

\author{
By: László Halpern and Gábor Körösi
}

William Davidson Working Paper Number 411

August 2001 


\title{
Mark-ups in Hungarian corporate sector ${ }^{\dagger}$
}

\author{
by
}

\section{László Halpern* and Gábor Körösi**}

\begin{abstract}
One of the major tasks facing a transition economy is to create the competitive environment of a properly functioning market economy. This paper attempts to analyse the relationship of market structure, market imperfections and corporate performance by mark-up pricing. There is a clear evidence for the existence of such market imperfections. However, these imperfections cannot be attributed to one single factor. We develop a varying coefficient model for the relationship between the factors facilitating rent-collection and the sectoral mark-ups.
\end{abstract}

JEL Classification: C23, D21, D24

Keywords: Firm in transition economy; market imperfections; mark-up pricing.

August 2001

$\dagger$ The financial support of EU Commission PHARE-ACE programme No. P97-8131-R and of OTKA No's T 019698 and T 029153 is gratefully acknowledged. We thank David Brown, Wendy Carlin, Rumen Dobrinsky, Réka Horváth, Mark Schaffer, and Jan Svejnar for their comments and suggestions to earlier versions of this paper.

* Institute of Economics of Hungarian Academy of Sciences, CEPR, WDI and CEU, Budaörsi 45, Budapest 1112, Hungary, Tel: +361-3092661, Fax: +361-3193136, email: halpern@econ.core.hu

** Institute of Economics of Hungarian Academy of Sciences and CEU, Budaörsi 45, Budapest 1112, Hungary, Tel: +361-3092671, Fax: +361-3193136, email: korosi@econ.core.hu 


\section{Introduction}

Our previous paper (Halpern and Körösi (2000)) was basically concerned with the productive efficiency of Hungarian firms. We used dynamic frontier production functions for the analysis. It was found that corporate performance followed a clearly visible path: Productive efficiency collapsed almost uniformly during the initial phase of the transition, but the very rapid consolidation period was followed by a period of gradual improvement starting around 1994-5. However, this recovery had very different characteristics for different groups of firms, basically according to ownership (foreign owned firms were more efficient than domestic ones) and size (small firms were clearly disadvantaged in the process).

Halpern and Körösi (2000) also tried to analyse the relationship between firm level efficiency and market structure. We found that market structure variables did not seem to have a strong influence on corporate performance, but there was a rather strong evidence of a reverse relationship: Efficient firms gain market share.

Centrally planned economies had a very highly concentrated market structure. There were only a very few firms in most sectors, and all industrial sectors were clearly dominated by a very small number of relatively large firms. These large firms could clearly use their market power in bargaining with central planners, thus their prices (formally fixed by the planners) were usually high enough that most companies seemed to be financially sound.

The situation quickly changed when transition started (in Hungary in 1988) with price and import liberalization, quickly followed by the substantial, although more gradual liberalization of capital markets. Many former oligopolists dwindled or disappeared as they had to compete with imports and newly emerging firms. Most former state-owned enterprises were privatized, and the larger ones were frequently sold to foreign investors. All these have completely reshaped the Hungarian corporate landscape by the mid-1990's. It does not necessarily mean that Hungarian manufacturing is much less concentrated than it used to be, but the new market leaders are private companies (frequently Hungarian subsidiaries of multinational corporations), and the corporate environment is completely different.

This paper attempts to identify the influence of this emerging market structure on corporate behaviour in a different way as our earlier studies. We use a mark-up pricing model for describing the consequences of market imperfections in the Hungarian manufacturing sector. This part follows the ideas developed by Hall (1988) and Roeger (1995).

The remainder of the study is organized as follows: Section 2 sets out the basic model for mark-up prices. Section 3 discusses data issues. Empirical findings are analysed in Section 4. Finally, conclusions are drawn. Appendix A explains notation and defines variables, while Appendix B presents results. 


\section{Mark-up pricing}

One of the most important results of production theory is that firms will set prices at their marginal cost in an efficiently competitive market. Only those firms having excess market power can achieve higher prices. As firms maximise profits, they will obviously recoup rents if possible. Thus, discrepancies between marginal cost and price, called mark-up, can be treated as indicators of market imperfections. In his seminal paper Hall (1988) developed a simple method for estimating mark-ups from Solow residuals.

Hall's measurement, however, is hampered by the endogeneity of the regressor. It is difficult to find truly exogenous instrumental variables. Roeger (1995) suggested an alternative measurement: The information contained in the production and in the dual cost functions are identical under the null hypothesis of perfectly competitive markets. Their systematic discrepancies thus must be the consequence of market imperfections, and their distance can be interpreted as a measure of mark-up pricing.

It is assumed that a Cobb-Douglas production function with constant returns to scale gives the correct description of the productive technology of any firm in a perfect market. The Solow residual is computed from both the primal production and the dual cost functions. The elasticity of labour $(\alpha)$ is estimated as the labour share of value added: $\alpha_{t}=W_{t} L_{t} / P_{t} Y_{t}$, where $P_{t}$ stands for the GDP deflator. The Solow residual from the production function (according to Hall (1988)) is:

$$
S R_{t}^{(p)}=\left(\Delta y_{t}-\Delta k_{t}\right)-\alpha_{t}\left(\Delta l_{t}-\Delta k_{t}\right)=B\left(\Delta y_{t}-\Delta k_{t}\right)-(1-B) \Delta e_{t},
$$

where lower case variables are logarithms and $B$ is the Lerner index, directly related to the mark-up of prices over the marginal cost $(\mu): \mu=1 /(1-B)$. The difficulty of the unbiased estimation of $B$ stems from the correlation between $\left(\Delta y_{t}-\Delta k_{t}\right)$ and $\Delta e_{t}$.

Roeger (1995) derived the corresponding Solow residuals for the dual cost function:

$$
S R_{t}^{(d)}=\alpha_{t} \Delta w_{t}+\left(1-\alpha_{t}\right) \Delta r_{t}-\Delta p_{t}=-B\left(\Delta p_{t}-\Delta r_{t}\right)+(1-B) \Delta e_{t}
$$

The difference of the two Solow residuals should just be a random noise. However, expressing their difference from the above expressions yields

$$
S R_{t}^{(p)}-S R_{t}^{(d)}=B \Delta x_{t}+u_{t}
$$

with $\Delta x_{t}=\left(\Delta y_{t}-\Delta k_{t}\right)+\left(\Delta p_{t}-\Delta r_{t}\right)=\Delta\left(p_{t} y_{t}\right)-\Delta\left(r_{t} k_{t}\right)$, i.e., $x_{t}$ is just the difference of the logarithmic growth rate of the nominal value added and capital cost. If $B=0$, i.e., the market is perfect, $\mu=1 /(1-B)=1$.

However, Oliveira Martins et al. (1996) show that mark-up ratios estimated from value added may be biased upwards and suggest to use the sales total instead. Hylleberg and Joergensen (1998) also show that mark-up estimates can be biased if the returns to scale is different from unity. Their paper also suggests, however, that the size of the bias is rather small, unless the returns to scale is substantially different from unity. 


\section{Data}

The database for this empirical study consists of the profit and loss account and balance sheet data of main Hungarian manufacturing firms between 1995 and 1998. ${ }^{1}$

The corporate dataset covers manufacturing firms employing at least 10 people. Sample selection is, however, biased towards large firms. The sample includes at least $15 \%$ of all manufacturing firms in every year, (usually more than 20\%), however, representation is much larger with respect to sales volume: at least $70 \%$ of manufacturing sales were at firms included in our sample every year.

Halpern and Körösi (2000) used a rather simplistic measure of competitive pressure, the number of firms in the sector, for lack of more appropriate information. We managed to get more detailed sectoral information for the present study. We experimented with several concentration measures: the Hirschmann-Herfindahl index, a distance measure, relative standard deviation, and the share of top three companies in the sector; all of them for employment and exports as well as for sales totals.

The models used in this study are based on a Cobb-Douglas production function. Capital is a key variable of such production models. It is always difficult to measure capital stock appropriately. It probably is an even more problematic task in a transition economy. The assets of practically all pre-existing firms were revalued at least once (frequently for several times), during the process of commercialisation and privatisation. This process was completed by 1995 at most firms, but not everywhere. The asset value could change substantially without any change in the physical composition of the capital, and the timing of the revaluation(s) is unknown. Inflation was not negligible in the period; we tried to calculate the capital stock at fixed prices, but that cannot be done very reliably for various reasons, one of which is the possibility of revaluation. These factors may certainly influence our results. However, their effect was relatively small in our sample period, compared to the previous period.

The cost of capital is an essential variable in the mark-up models. However, the measurement of the cost of capital is probably the most problematic task for Hungary, using corporate balance sheets. There are many firms with clearly invalid reported depreciation: For more than $10 \%$ of the sample depreciation is either greater than half the net value of fixed assets, or less than $1 \%$ of the value of fixed assets, both of which is impossible. Apparently some firms use depreciation as a balancing item in their books: This is the only relatively large expenditure item which does not have to be substantiated by bills. Approximately $25 \%$ of the firms reported 0 profits with the precision of our observations (one million forints); for more than half of these firms the rounding error was less than $0.5 \%$ of the sales total. We suspect that many such firms applied creative accounting practices to avoid the necessity of reporting either losses or profits.

When we tried to use a cost of capital variable computed from these depreciation figures we got weird results. We believe that those results are the consequences of systematic biases in reporting. The cost of capital was approximated in a model consistent way

1 We would like to express our gratitude to Mr. József Becsei and his collaborators for their help in compiling the revised and extended data base. 
instead: Under the assumption of Cobb-Douglas technology with unit returns to scalewhich is the maintained hypothesis in the mark-up pricing model we use - value added is decomposed to wage cost and capital cost. As the value added and wage bill are given, the cost of capital was calculated as their difference. This way we certainly introduce an unknown, but substantial measurement error into the cost of capital variable; we tried to deal with that in the estimation process.

\section{Empirical evidence of mark-up pricing}

The derivation of a mark-up based measure of market imperfections in Section 2 is built on the maintained hypothesis of Cobb-Douglas technology with constant returns to scale. The assumption of constant returns to scale, however, is clearly invalid for the transitional recession, when returns to scale was much below unity. As it is evident from our former production function estimates, reported in Halpern and Körösi (2000) that the returns to scale becomes one, or slightly larger in 1995. In fact, when static production models are estimated for the Hungarian corporate sector annually (the Hall-Roeger measurement is based on a static model), the unit returns to scale assumption is not rejected for the period after 1994 (c.f., Halpern and Körösi (1998a) and (1998b)). Evidence presented by Hylleberg and Joergensen (1998) suggests that this small discrepancy from the constant returns to scale are unlikely to exert a substantial influence on our results.

As it was pointed out in the data section, our capital cost variable is rather noisy. It certainly includes a substantial measurement error. Even if we assume that this measurement error is independent of the error term $u_{t}$, the OLS estimator of $B$ will be (downward) biased. Thus, the mark-up estimates are also downward biased by the measurement error. Good instruments would obviously solve the problem, however, our information set basically is the balance sheet of the firm: Thus, the measurement error of the cost of capital may not be independent of the information derived from the balance sheets. Alternatively, we may assume that this measurement error is firm specific, in which case differencing eliminates the constant firm specific effect.

Thus, mark-up ratios were estimated from panel data covering the period when the constant returns to scale assumption seems to be valid, i.e., for 1995-8, and for each sector separately. We used both value added and sales total; the estimated mark-up are presented in Tables 1 (for two digit NACE sectors) and 2 (for three digit sectors). Figures 1-8 present graphic pictures of the empirical distribution of mark-ups estimated from value added, or sales, at the three and four digits levels.

There are some differences among the various mark-up estimates. Curiously, and contrary to our expectations, mark-ups estimated from value added tend to be smaller than the ones estimated from total sales. These latter mark-ups are higher than expected on average. However, it is obvious that the estimated $\mu$ is significantly greater than 1 for most of the sectors.

These estimated mark-ups provide clear evidence of market imperfections. It is possible to identify the sectors where market seems to be the most distorted. However, different model estimates sometimes give contradictory rankings of the sectors by the magnitude 
of apparent market distortions. For example, all four two digit estimates agree that the mark-up in sector 25 (Rubber and plastic products) is higher than usual, however, for sector 24 (Chemical materials, etc) the results are ambiguous. And at three or four digit level the evidence seems to be less and less homogeneous. Thus it seems that it is not sufficient to estimate these mark-ups. We would also like to know the factors influencing market imperfections, and their importance.

The obvious proposition is to relate market imperfections to the structure of the market. One could do that by regressing mark-ups on variables describing some charecteristics of the market structure. ${ }^{2}$ However, as we use panel estimates, we only have one single estimated mark-up for the entire period of 1995-8, instead of having a separate observation for each sector each year, while market structure variables are measured annually.

As the mark-up is just a transformed value of the Lerner index, which is a single parameter estimated in the model, we rather assume that this parameter is not constant over the entire sample. We employ a simple varying coefficient model:

$$
S R_{i, t}^{(p)}-S R_{i, t}^{(d)}=B_{i, t}\left(z_{i, t}\right) \Delta x_{i, t}+u_{i, t},
$$

where the parameter $B_{i, t}$ is a linear function of variables $z_{i, t}$. This solution provides an implicit explanation of factors driving mark-up ratios.

We experimented with several sets of explanatory variables. First, we just described changes of the Lerner index by lagged market share, import penetration and concentration. We estimated the model using several alternative concentration measures; Tables 3 and 4 summarize these results. While market structure variables significantly influence mark-ups for many sectors, there is not one single case which stands out as the one clearly dominating all other. Interestingly, while concentration was irrelevant for explaining corporate performance, this seems to be the most important market structure variable enabling companies to charge prices in excess of their marginal costs. However, all three market structure variables are usually not significant individually. This may indicate multicollinearity among the variables; however, it is likely that not all three variables influence mark-ups with the same intensity.

An alternative possibility is that market imperfections are also related to other factors; most importantly to ownership. Ownership causes very characteristic differences in corporate efficiency; it may also be related to market imperfections. Ownership structure may obviously influence the ability of firms to exploit market imperfections. When analysing productive efficency, we found significant structural breaks among firms by ownership categories, indicating different productive practices, which may be related to differences in corporate culture. That may certainly influence the behaviour of firms. However, sample sizes in most sectors are too small for testing for structural breaks by ownership and splitting the sample accordingly. Instead of exploring structural breaks the same way as we did when studying efficiency, we alternatively assumed that $B_{i, t}$ depends on ownership variables rather than on market share or import penetration, keeping the probably best performing measure of concentration: the relative standard deviation of the production. As the different estimates give very similar results, we only present the most consistent one: value added based estimation with random effects. Table 5 summarizes estimation results

2 For example, Markov et al. (2000) and Dobrinsky (2001) folow that route. 
for two digit sectors. Ownership seems to matter for many sectors, although not for all. Foreign owned firms tend to have higher markups than other firms, while - surprisinglydomestic private firms seem to have lower markups on the average than other firms in the same sector.

\section{Conclusions}

Halpern and Körösi (2000) found some evidence of market structure influencing corporate performance. However, that evidence was not very strong, and mostly stemmed from the market share of the firm. Curiously, concentration did not seem to have any effect on performance.

When analysing mark-up pricing, however, we find that the probably most important factor is concentration in distinguishing between sectors where prices are equal to marginal cost and where they exceed that.

Our results clearly indicate that substantial market imperfections exist in the Hungarian manufacturing sector. These imperfections can yield substantial rents. ${ }^{3}$ However, foreign owned firms seem to have a larger chance for exploiting market imperfections and can collect larger rents than domestic firms. As many foreign firms are Hungarian subsidiaries of multinationals, this may just indicate that their true market power cannot be correctly assessed from the balance sheets of this Hungarian subsidiary. Private firms, owned by domestic investors, on the other hand, seem to be less able to recoup rents from their market power than firms (at least to a significant extent) owned by the state. This indicates that state ownership probably still provides firms with some residual bargaining power against authotorities, enabling them to rig the markets to a limited extent.

3 The mark-ups estimated for Hungarian firms are much higher on average than mark-ups estimated for Bulgarian manufacturing firms by Markov et al. (2000) and Dobrinsky (2001). 


\section{References}

Aghion, P., Blanchard, O.J. and Carlin, W. (1994): The Economics of Enterprise Restructuring in Central and Eastern Europe; CEPR Discussion Paper 1058.

Dobrinsky, R., Nikolov, B. and Markov, N. (2001): Mark-up Pricing in Bulgarian Manufacturing; Mimeo.

Estrin, S. and Hare, P. (1992): Firms in Transition: Modelling Enterprise Adjustment; Centre for Economic Performance, LSE Discussion Paper No. 89, p. 42.

Hall, R. (1988): The Relation between Price and Marginal Cost in U.S. Industry; Journal of Political Economy, 96(51), pp. 921-947.

Halpern, L. and G. Körösi (1998a): Corporate Performance in Transition (Econometric Analysis of Hungarian Exporting Firms, 1985-1994); in: Halpern, L. and C. Wyplosz (Eds.): Hungary: Towards a Market Economy; Cambridge University Press pp. $192-212$.

Halpern, L. and G. Körösi (1998b): Corporate Structure and Performance in Hungary; William Davidson Institute Working Paper Series No. 187 p. 28.

Halpern, L. and G. Körösi (2000): Efficiency and Market Share in Hungarian Corporate Sector; CEPR working paperNo. 2544, pp. 38.

Harrison, A. (1994): Productivity, Imperfect Competition and Trade Reform: Theory and Evidence', Journal of International Economics, Vol. 36, pp. 53-73.

Hylleberg, S. and R. Joergensen (1998): A Note on the Estimation of Markup Pricing in Manufacturing; University of Aarhus, working paper No. 1998-6.

Lavoie, M. (1996): Mark-Up Pricing versus Normal Cost Pricing in Post-Keynesian Models; Review of Political Economy, Vol. 8, No. 1, pp. 57-66.

Markov, N., Nikolov, B. and Dobrinsky, R. (2000): Competitive pressure, efficiency and mark-up pricing in Bulgarian manufacturing; Mimeo, p. 37.

Oliveira Martins, J., Scarpetta, S. and Pilat, D. (1996): Mark-up Ratios in Manufacturing Industries; Estimations for 14 OECD Countries, OECD Economics Department Working Papers No. 162.

Roeger, W. (1995): Can Imperfect Competition Explain Differences between Primal and Dual Productivity Measures? Estimates for US Manufacturing; Journal of Political Economy, Vol. 103, No. 2, pp. 316-330. 


\section{Appendix A: Definitions}

All variables (except employment) were deflated, usually with four digit sectoral producer price indices. There were some - usually small - sectors, where the price index was only available at a higher level of aggregation ( 2 or 3 digit sectors). Variables are measured in million Forints at 1991 prices. The variables are:

Valued added (Y): Sales less broadly defined material costs.

Labour (L): Annual average employment at the firm.

Cost of labour (W): Annual wage bill relative to average employment at the firm.

Capital (K): Fixed assets. See data section for qualifications.

Cost of capital (R): Value added less wage bill relative to fixed assets. See data section for qualifications.

Market share: Sales of the firm divided by the market size, where market size is the sectoral production plus competing imports less exports, all measured at the NACE four digit sectoral level. The sectoral classification of imports is based on the four-digit product classification.

Import penetration: The ratio of the sectoral imports to the above defined market size.

Concentration: Herfindahl-Hirschmann index of concentration of total sales, measured at the NACE four digit sectoral level.

State owned firm: A firm where the central and local governments together owned more than $50 \%$ of the equity capital.

Foreign owned firm: Foreign investors owned more than $50 \%$ of the equity capital.

Foreign owned firm: Domestic private investors owned more than $50 \%$ of the equity capital.

Legend to the tables: Asterisks after the coefficients and test statistics indicate that the test is significant at 0.05 level $(*)$ or at 0.01 level $(* *)$. Wald test is the joint test for no varying components in $B$. The null of the t-test on mark-up is that $\mu=1 . \bar{\mu}$ is the average mark-up in the sector. 


\section{Appendix B: Selected estimation results}

Table 1: Estimated markup, 2 digits level, based on

\begin{tabular}{|l|l|l|l|l|l|l|l|l|}
\hline & \multicolumn{5}{|c|}{ Value added } & \multicolumn{5}{|c|}{ Sales total } \\
\hline Nace & Random effects & $\mathrm{R}^{2}$ & Fixed effects & $\mathrm{R}^{2}$ & Random effects & $\mathrm{R}^{2}$ & Fixed effects & $\mathrm{R}^{2}$ \\
\hline 15 & $1.18 * *$ & 0.24 & $1.16 * *$ & 0.60 & $1.46 * *$ & 0.53 & $1.42 * *$ & 0.72 \\
16 & 1.16 & 0.45 & 1.16 & 0.84 & $1.51 * *$ & 0.77 & $1.50 * *$ & 0.92 \\
17 & $1.13 * *$ & 0.19 & $1.11 * *$ & 0.54 & $1.30 * *$ & 0.38 & $1.30 * *$ & 0.59 \\
18 & $1.08 * *$ & 0.15 & $1.07 * *$ & 0.60 & $1.19 * *$ & 0.28 & $1.19 * *$ & 0.54 \\
19 & $1.13 * *$ & 0.24 & $1.14 * *$ & 0.62 & $1.27 * *$ & 0.33 & $1.29 * *$ & 0.71 \\
20 & $1.18 * *$ & 0.18 & $1.21 * *$ & 0.60 & $1.32 * *$ & 0.39 & $1.39 * *$ & 0.65 \\
21 & $1.21 * *$ & 0.29 & $1.14 * *$ & 0.59 & $1.40 * *$ & 0.56 & $1.38 * *$ & 0.69 \\
22 & $1.2 * *$ & 0.43 & $1.26 * *$ & 0.62 & $1.50 * *$ & 0.60 & $1.47 * *$ & 0.74 \\
24 & $1.21 * *$ & 0.25 & $1.21 * *$ & 0.65 & $1.62 * *$ & 0.65 & $1.66 * *$ & 0.80 \\
25 & $1.41 * *$ & 0.47 & $1.35 * *$ & 0.70 & $1.52 * *$ & 0.60 & $1.49 * *$ & 0.76 \\
26 & $1.20 * *$ & 0.28 & $1.21 * *$ & 0.60 & $1.41 * *$ & 0.52 & $1.44 * *$ & 0.71 \\
27 & $1.16 * *$ & 0.21 & $1.18 * *$ & 0.65 & $1.39 * *$ & 0.50 & $1.44 * *$ & 0.77 \\
28 & $1.17 * *$ & 0.26 & $1.16 * *$ & 0.62 & $1.32 * *$ & 0.39 & $1.33 * *$ & 0.64 \\
29 & $1.21 * *$ & 0.26 & $1.18 * *$ & 0.57 & $1.39 * *$ & 0.43 & $1.39 * *$ & 0.61 \\
30 & $1.45 * *$ & 0.54 & $1.27 *$ & 0.84 & $1.94 * *$ & 0.76 & $1.88 * *$ & 0.85 \\
31 & $1.39 * *$ & 0.44 & $1.41 * *$ & 0.61 & $1.57 * *$ & 0.57 & $1.59 * *$ & 0.70 \\
32 & $1.42 * *$ & 0.49 & $1.29 * *$ & 0.85 & $1.64 * *$ & 0.55 & $1.49 * *$ & 0.81 \\
33 & $1.17 * *$ & 0.30 & $1.13 * *$ & 0.67 & $1.33 * *$ & 0.43 & $1.30 * *$ & 0.69 \\
34 & $1.18 * *$ & 0.26 & $1.17 * *$ & 0.58 & $1.42 * *$ & 0.43 & $1.44 * *$ & 0.62 \\
35 & 1.06 & 0.07 & 1.06 & 0.35 & $1.18 * *$ & 0.26 & $1.19 * *$ & 0.59 \\
36 & $1.14 * *$ & 0.29 & $1.08 * *$ & 0.77 & $1.30 * *$ & 0.44 & $1.23 * *$ & 0.71 \\
37 & 1.00 & 0.01 & 1.07 & 0.70 & $1.28 * *$ & 0.43 & $1.35 * *$ & 0.76 \\
\hline
\end{tabular}


Table 2: Estimated markup, 3 digits level, based on

\begin{tabular}{|c|c|c|c|c|c|c|c|c|}
\hline & \multicolumn{4}{|c|}{ Value added } & \multicolumn{4}{|c|}{ Sales total } \\
\hline Nace & Random effects & $\mathrm{R}^{2}$ & Fixed effects & $\mathrm{R}^{2}$ & Random effects & $\mathrm{R}^{2}$ & Fixed effects & $\mathrm{R}^{2}$ \\
\hline 151 & $1.13 * *$ & 0.28 & $1.12 * *$ & 0.66 & $1.39 * *$ & 0.52 & $1.34 * *$ & 0.75 \\
\hline 153 & $1.32 * *$ & 0.32 & $1.38 * *$ & 0.73 & $1.58 * *$ & 0.61 & $1.63 * *$ & 0.82 \\
\hline 154 & 0.99 & 0.13 & 1.06 & 0.27 & 1.27 & 0.24 & 1.42 & 0.33 \\
\hline 155 & $1.06 * *$ & 0.15 & $1.04 *$ & 0.59 & $1.24 * *$ & 0.48 & $1.19 * *$ & 0.69 \\
\hline 156 & $1.24 * *$ & 0.27 & $1.26 * *$ & 0.55 & $1.54 * *$ & 0.62 & $1.51 * *$ & 0.77 \\
\hline 157 & $1.52 * *$ & 0.57 & $1.43 * *$ & 0.72 & $1.91 * *$ & 0.73 & $1.82 * *$ & 0.81 \\
\hline 158 & $1.16 * *$ & 0.23 & $1.12 * *$ & 0.65 & $1.39 * *$ & 0.51 & $1.36 * *$ & 0.72 \\
\hline 159 & $1.12 * *$ & 0.12 & $1.11 *$ & 0.51 & $1.49 * *$ & 0.44 & $1.51 * *$ & 0.67 \\
\hline 160 & 1.16 & 0.45 & 1.16 & 0.84 & $1.51 * *$ & 0.77 & $1.50 * *$ & 0.92 \\
\hline 171 & 1.02 & 0.21 & 1.01 & 0.52 & $1.34 * *$ & 0.32 & $1.35 *$ & 0.50 \\
\hline 172 & 1.04 & 0.12 & 1.04 & 0.51 & $1.14 * *$ & 0.32 & $1.14 * *$ & 0.74 \\
\hline 173 & 1.12 & 0.48 & 1.15 & 0.61 & $1.15 * *$ & 0.63 & 1.12 & 0.75 \\
\hline 174 & $1.09 * *$ & 0.22 & $1.08 * *$ & 0.55 & $1.23 * *$ & 0.40 & $1.26 * *$ & 0.57 \\
\hline 175 & $1.12 * *$ & 0.25 & $1.11 * *$ & 0.54 & $1.22 * *$ & 0.44 & $1.21 * *$ & 0.58 \\
\hline 176 & $1.96 * *$ & 0.64 & $1.79 *$ & 0.83 & $2.34 * *$ & 0.78 & $2.19 *$ & 0.89 \\
\hline 177 & $1.15 * *$ & 0.29 & $1.13 *$ & 0.59 & $1.75 * *$ & 0.57 & $1.77 * *$ & 0.77 \\
\hline 182 & $1.08 * *$ & 0.15 & $1.07 * *$ & 0.60 & $1.19 * *$ & 0.28 & $1.19 * *$ & 0.55 \\
\hline 183 & $1.11 * *$ & 0.57 & $1.11 * *$ & 0.90 & $1.35 * *$ & 0.74 & 1.30 & 0.84 \\
\hline 191 & 0.93 & 0.37 & 1.03 & 0.79 & 1.04 & 0.14 & 1.12 & 0.90 \\
\hline 192 & $1.10 * *$ & 0.37 & $1.08 * *$ & 0.84 & $1.22 * *$ & 0.37 & $1.17 * *$ & 0.76 \\
\hline 193 & $1.13 * *$ & 0.24 & $1.15 * *$ & 0.60 & $1.28 * *$ & 0.34 & $1.30 * *$ & 0.71 \\
\hline 201 & $1.30 * *$ & 0.49 & $1.29 * *$ & 0.70 & $1.53 * *$ & 0.67 & $1.53 * *$ & 0.80 \\
\hline 202 & 1.20 & 0.24 & $1.54 *$ & 0.58 & $1.47 * *$ & 0.49 & $1.65 * *$ & 0.85 \\
\hline 203 & $1.15 * *$ & 0.09 & $1.20 * *$ & 0.61 & $1.24 * *$ & 0.27 & $1.35 * *$ & 0.60 \\
\hline 204 & $1.23 * *$ & 0.35 & $1.22 * *$ & 0.56 & $1.31 * *$ & 0.50 & $1.32 * *$ & 0.66 \\
\hline 205 & $1.10 * *$ & 0.18 & $1.11 * *$ & 0.57 & $1.26 * *$ & 0.36 & $1.31 * *$ & 0.54 \\
\hline 211 & $1.20 * *$ & 0.30 & $1.21 *$ & 0.87 & $1.27 *$ & 0.46 & 1.31 & 0.79 \\
\hline 212 & $1.23 * *$ & 0.30 & $1.14 * *$ & 0.56 & $1.43 * *$ & 0.60 & $1.40 * *$ & 0.71 \\
\hline 221 & $1.30 * *$ & 0.48 & $1.32 * *$ & 0.72 & $1.61 * *$ & 0.68 & $1.67 * *$ & 0.82 \\
\hline 222 & $1.28 * *$ & 0.42 & $1.25 * *$ & 0.60 & $1.45 * *$ & 0.58 & $1.40 * *$ & 0.71 \\
\hline 223 & 0.83 & 0.31 & 0.82 & 0.72 & 1.07 & 0.19 & 1.06 & 0.65 \\
\hline 241 & $1.13 * *$ & 0.12 & $1.16 * *$ & 0.64 & $1.59 * *$ & 0.66 & $1.70 * *$ & 0.81 \\
\hline 242 & $1.52 * *$ & 0.58 & $1.47 * *$ & 0.86 & $2.26 * *$ & 0.91 & $2.25 * *$ & 0.95 \\
\hline 243 & $1.17 * *$ & 0.19 & $1.14 *$ & 0.47 & $1.59 * *$ & 0.68 & $1.60 * *$ & 0.76 \\
\hline 244 & $1.15 * *$ & 0.18 & $1.11 *$ & 0.60 & $1.60 * *$ & 0.71 & $1.64 * *$ & 0.82 \\
\hline 245 & $1.55 * *$ & 0.62 & $1.52 * *$ & 0.79 & $1.90 * *$ & 0.73 & $1.79 * *$ & 0.85 \\
\hline 246 & $1.23 * *$ & 0.31 & $1.19 * *$ & 0.75 & $1.46 * *$ & 0.61 & $1.42 * *$ & 0.79 \\
\hline 251 & $1.21 * *$ & 0.45 & $1.14 * *$ & 0.86 & $1.45 * *$ & 0.63 & $1.33 * *$ & 0.80 \\
\hline 252 & $1.44 * *$ & 0.48 & $1.39 * *$ & 0.70 & $1.53 * *$ & 0.60 & $1.52 * *$ & 0.76 \\
\hline 261 & 1.05 & 0.08 & 1.06 & 0.36 & $1.28 * *$ & 0.36 & $1.34 * *$ & 0.54 \\
\hline 262 & $1.18 * *$ & 0.33 & $1.20 * *$ & 0.54 & $1.39 * *$ & 0.45 & $1.46 * *$ & 0.57 \\
\hline 263 & $1.76 * *$ & 0.76 & $1.76 * *$ & 0.97 & $1.63 * *$ & 0.90 & $1.62 * *$ & 1.00 \\
\hline 264 & $1.14 * *$ & 0.15 & $1.18 * *$ & 0.64 & $1.47 * *$ & 0.50 & $1.51 * *$ & 0.74 \\
\hline 265 & $1.56 * *$ & 0.65 & 4.29 & 0.73 & $1.48 * *$ & 0.79 & $1.75 *$ & 0.90 \\
\hline 266 & $1.31 * *$ & 0.50 & $1.30 * *$ & 0.72 & $1.49 * *$ & 0.70 & $1.47 * *$ & 0.80 \\
\hline 268 & $1.16 * *$ & 0.31 & $1.20 * *$ & 0.69 & $1.35 * *$ & 0.50 & $1.41 * *$ & 0.84 \\
\hline
\end{tabular}


Table 2: (Continued)

\begin{tabular}{|c|c|c|c|c|c|c|c|c|}
\hline & \multicolumn{4}{|c|}{ Value added } & \multicolumn{4}{|c|}{ Sales total } \\
\hline Nace & Random effects & $\mathrm{R}^{2}$ & Fixed effects & $\mathrm{R}^{2}$ & Random effects & $\mathrm{R}^{2}$ & Fixed effects & $\mathrm{R}^{2}$ \\
\hline 265 & $1.56 * *$ & 0.65 & 4.29 & 0.73 & $1.48 * *$ & 0.79 & $1.75 *$ & 0.90 \\
\hline 266 & $1.31 * *$ & 0.50 & $1.30 * *$ & 0.72 & $1.49 * *$ & 0.70 & $1.47 * *$ & 0.80 \\
\hline 268 & $1.16 * *$ & 0.31 & $1.20 * *$ & 0.69 & $1.35 * *$ & 0.50 & $1.41 * *$ & 0.84 \\
\hline 271 & $1.09 * *$ & 0.37 & $1.11 *$ & 0.68 & $1.38 * *$ & 0.72 & $1.46 * *$ & 0.92 \\
\hline 272 & $1.16 *$ & 0.30 & $1.17 *$ & 0.92 & $1.28 * *$ & 0.58 & 1.27 & 0.69 \\
\hline 273 & $1.10 *$ & 0.00 & $1.20 * *$ & 0.93 & $1.21 *$ & 0.07 & $1.44 * *$ & 0.84 \\
\hline 274 & $1.48 * *$ & 0.51 & $1.42 *$ & 0.64 & $1.66 * *$ & 0.78 & $1.59 * *$ & 0.91 \\
\hline 275 & $1.15 * *$ & 0.33 & $1.14 * *$ & 0.70 & $1.34 * *$ & 0.53 & $1.35 * *$ & 0.69 \\
\hline 281 & $1.14 * *$ & 0.20 & $1.15 * *$ & 0.61 & $1.25 * *$ & 0.31 & $1.28 * *$ & 0.59 \\
\hline 282 & $1.08 * *$ & 0.10 & $1.07 *$ & 0.58 & $1.18 * *$ & 0.18 & $1.24 * *$ & 0.52 \\
\hline 283 & $1.43 * *$ & 0.60 & $1.51 * *$ & 0.85 & $1.63 * *$ & 0.67 & $1.81 * *$ & 0.89 \\
\hline 284 & $1.28 * *$ & 0.52 & $1.43 * *$ & 0.83 & $2.30 * *$ & 0.82 & $2.68 * *$ & 0.94 \\
\hline 285 & $1.22 * *$ & 0.35 & $1.18 * *$ & 0.62 & $1.39 * *$ & 0.47 & $1.37 * *$ & 0.70 \\
\hline 286 & $1.24 * *$ & 0.48 & $1.26 * *$ & 0.69 & $1.42 * *$ & 0.55 & $1.43 * *$ & 0.74 \\
\hline 287 & $1.22 * *$ & 0.34 & $1.18 * *$ & 0.65 & $1.45 * *$ & 0.57 & $1.39 * *$ & 0.73 \\
\hline 291 & $1.38 * *$ & 0.52 & $1.35 * *$ & 0.68 & $1.60 * *$ & 0.66 & $1.60 * *$ & 0.79 \\
\hline 292 & $1.32 * *$ & 0.35 & $1.28 * *$ & 0.62 & $1.58 * *$ & 0.53 & $1.59 * *$ & 0.69 \\
\hline 293 & $1.16 * *$ & 0.22 & $1.16 * *$ & 0.47 & $1.30 * *$ & 0.44 & $1.31 * *$ & 0.62 \\
\hline 294 & 1.06 & 0.13 & 1.01 & 0.65 & $1.16 * *$ & 0.19 & 1.13 & 0.50 \\
\hline 295 & $1.08 * *$ & 0.13 & $1.06 * *$ & 0.55 & $1.21 * *$ & 0.33 & $1.20 * *$ & 0.53 \\
\hline 297 & $1.40 * *$ & 0.51 & $1.43 * *$ & 0.71 & $1.51 * *$ & 0.57 & $1.55 * *$ & 0.70 \\
\hline 300 & $1.45 * *$ & 0.54 & $1.27 *$ & 0.84 & $1.94 * *$ & 0.76 & $1.88 * *$ & 0.85 \\
\hline 311 & $1.09 * *$ & 0.26 & $1.08 * *$ & 0.45 & $1.26 * *$ & 0.43 & $1.26 * *$ & 0.55 \\
\hline 312 & $1.38 * *$ & 0.38 & $1.37 * *$ & 0.54 & $1.73 * *$ & 0.57 & $1.74 * *$ & 0.69 \\
\hline 313 & 1.00 & 0.12 & 0.98 & 0.48 & $1.30 * *$ & 0.32 & 1.51 & 0.50 \\
\hline 314 & $1.45 * *$ & 0.76 & 1.28 & 0.94 & $2.04 * *$ & 0.90 & $2.12 * *$ & 0.95 \\
\hline 315 & $1.22 * *$ & 0.48 & $1.25 * *$ & 0.67 & $1.35 * *$ & 0.60 & $1.35 * *$ & 0.75 \\
\hline 316 & $1.71 * *$ & 0.61 & $1.73 * *$ & 0.73 & $1.86 * *$ & 0.68 & $1.86 * *$ & 0.79 \\
\hline 321 & $1.22 * *$ & 0.29 & $1.24 * *$ & 0.67 & $1.34 * *$ & 0.40 & $1.36 * *$ & 0.73 \\
\hline 322 & $2.11 * *$ & 0.79 & $1.53 * *$ & 0.93 & $2.58 * *$ & 0.81 & $2.06 * *$ & 0.90 \\
\hline 323 & $1.15 * *$ & 0.32 & $1.17 * *$ & 0.61 & $1.30 * *$ & 0.31 & $1.31 * *$ & 0.68 \\
\hline 331 & $1.20 * *$ & 0.40 & $1.15 * *$ & 0.67 & $1.39 * *$ & 0.61 & $1.36 * *$ & 0.71 \\
\hline 332 & $1.10 * *$ & 0.22 & $1.09 * *$ & 0.68 & $1.21 * *$ & 0.29 & $1.21 * *$ & 0.65 \\
\hline 333 & $1.99 * *$ & 0.72 & 1.58 & 0.80 & $2.77 * *$ & 0.85 & 1.61 & 0.93 \\
\hline 334 & $1.11 * *$ & 0.37 & $1.10 *$ & 0.61 & $1.23 * *$ & 0.39 & $1.25 * *$ & 0.61 \\
\hline 341 & 1.01 & 0.00 & 1.17 & 0.86 & $1.40 *$ & 0.16 & $1.83 *$ & 0.86 \\
\hline 342 & $1.26 * *$ & 0.33 & $1.25 *$ & 0.53 & $2.01 * *$ & 0.72 & $1.91 * *$ & 0.79 \\
\hline 343 & $1.19 * *$ & 0.33 & $1.16 * *$ & 0.60 & $1.32 * *$ & 0.41 & $1.31 * *$ & 0.60 \\
\hline 352 & $1.24 * *$ & 0.53 & $1.22 * *$ & 0.65 & $1.27 * *$ & 0.64 & $1.24 * *$ & 0.77 \\
\hline 353 & $1.13 * *$ & 0.88 & $1.12 * *$ & 0.95 & $1.25 * *$ & 0.75 & 1.20 & 0.81 \\
\hline 355 & $1.44 * *$ & 0.89 & $1.41 * *$ & 0.94 & $1.71 * *$ & 0.87 & $1.74 * *$ & 0.92 \\
\hline 361 & $1.11 * *$ & 0.26 & $1.06 * *$ & 0.79 & $1.26 * *$ & 0.41 & $1.19 * *$ & 0.71 \\
\hline 362 & $1.12 *$ & 0.51 & 1.13 & 0.75 & 1.26 & 0.52 & 1.24 & 0.80 \\
\hline 364 & 1.05 & 0.11 & 1.02 & 0.74 & 1.60 & 0.49 & 1.43 & 0.68 \\
\hline 366 & $1.40 * *$ & 0.69 & $1.30 * *$ & 0.85 & $1.57 * *$ & 0.77 & $1.53 * *$ & 0.84 \\
\hline 371 & 0.96 & 0.14 & 1.05 & 0.69 & $1.25 * *$ & 0.44 & $1.37 * *$ & 0.72 \\
\hline
\end{tabular}




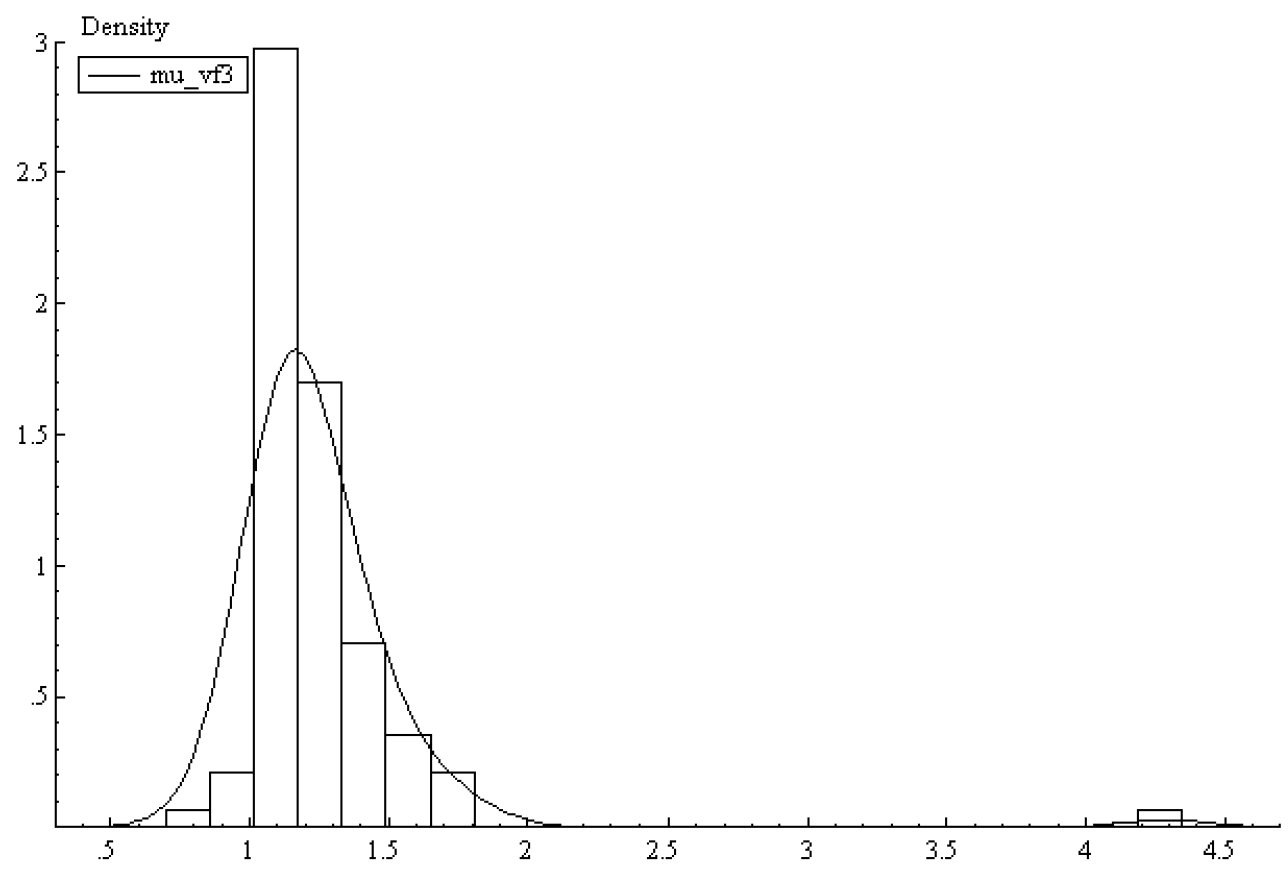

Figure 1. Histogram of markups estimated from value added at NACE3, fixed effects

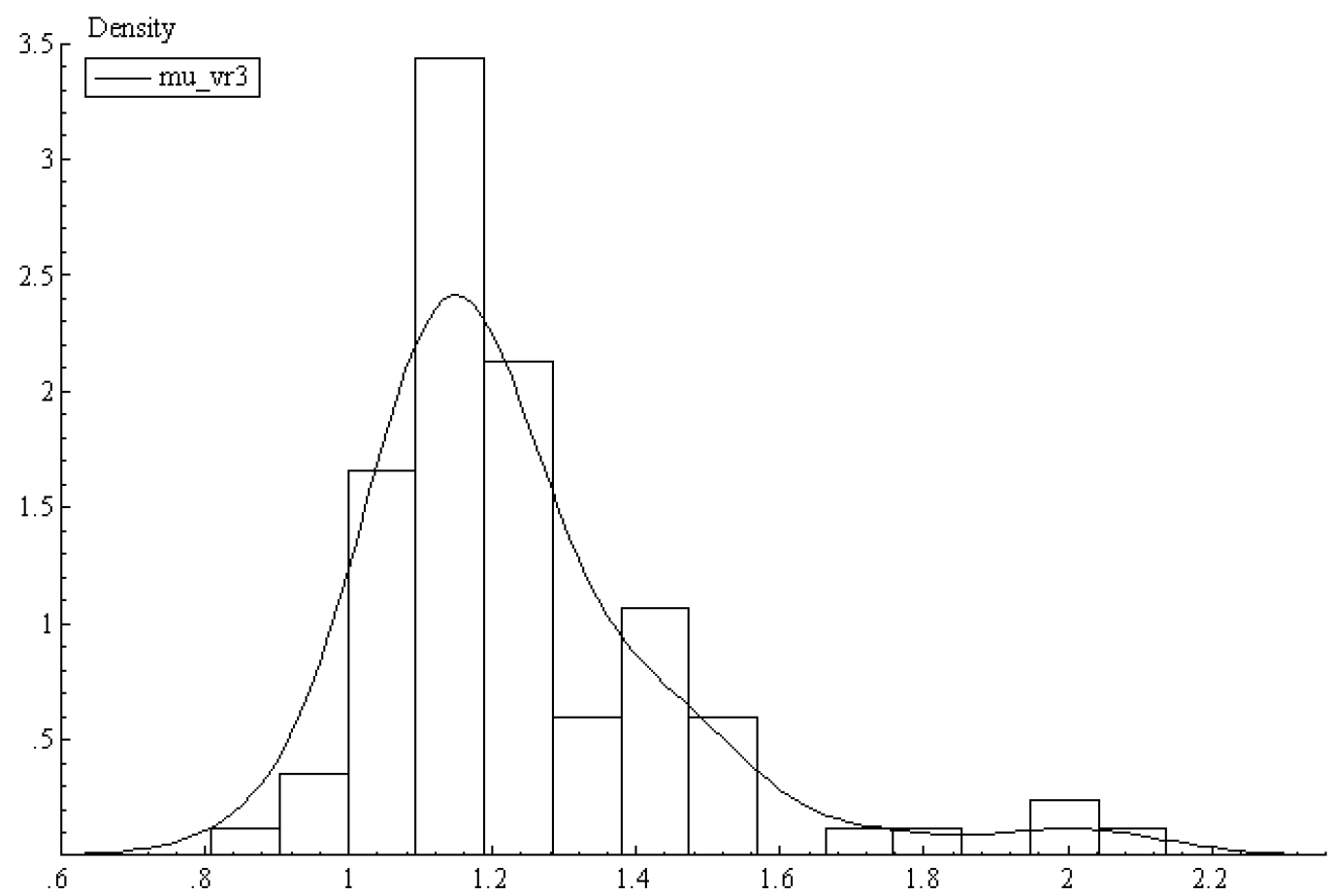

Figure 2. Histogram of markups estimated from value added at NACE3, random effects 


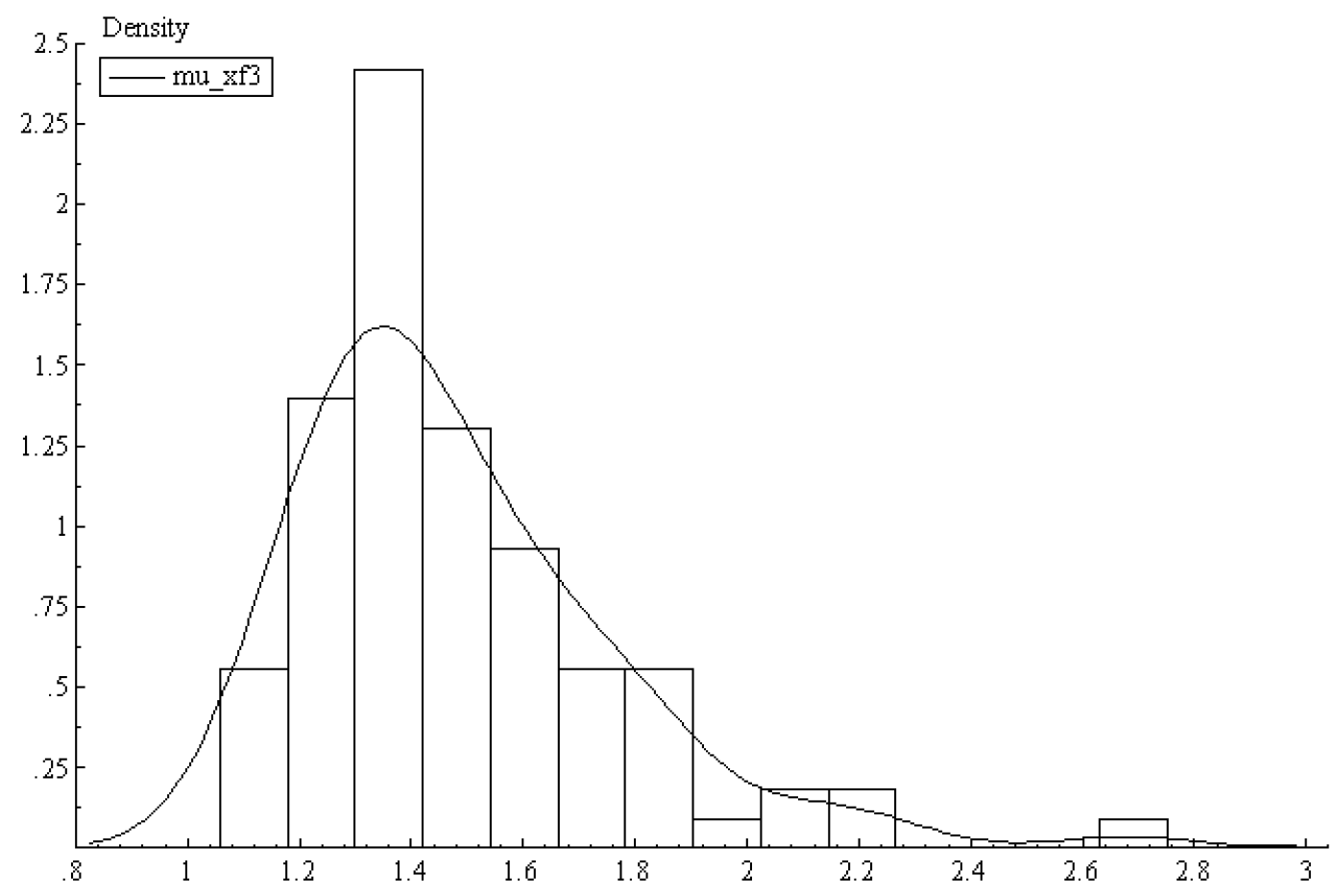

Figure 3. Histogram of markups estimated from sales at NACE3, fixed effects

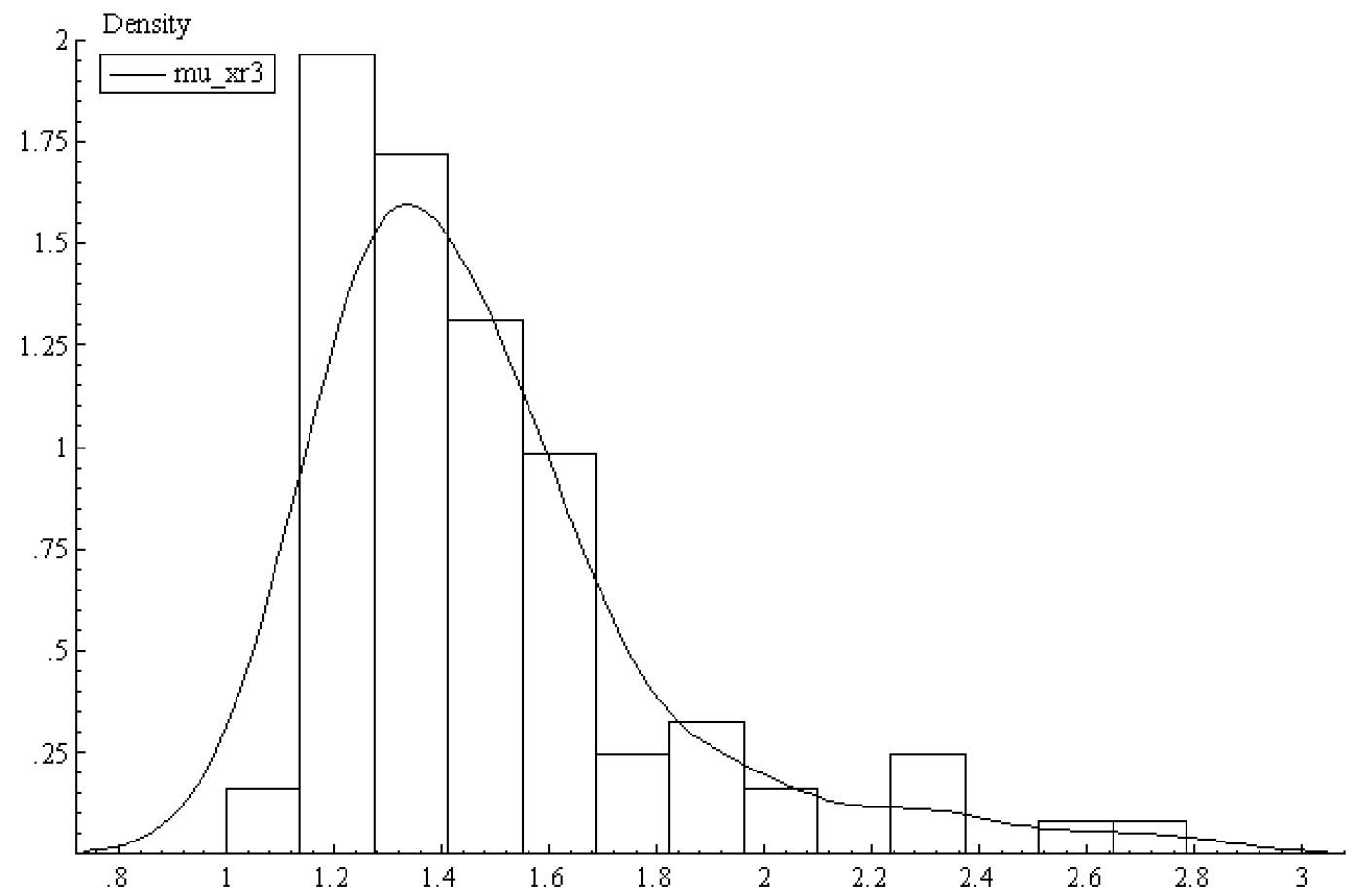

Figure 4. Histogram of markups estimated from sales at NACE3, random effects 


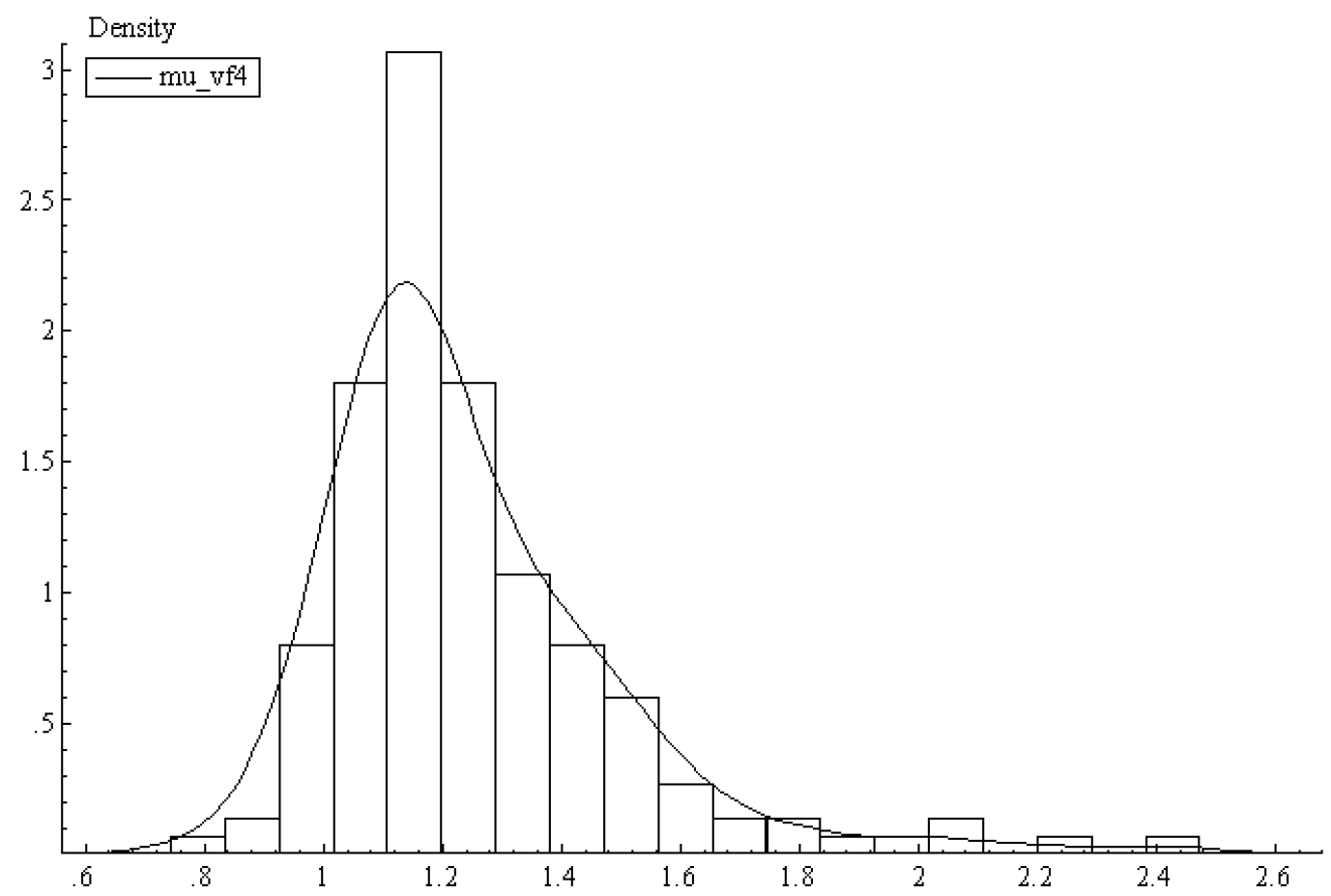

Figure 5. Histogram of markups estimated from value added at NACE4, fixed effects

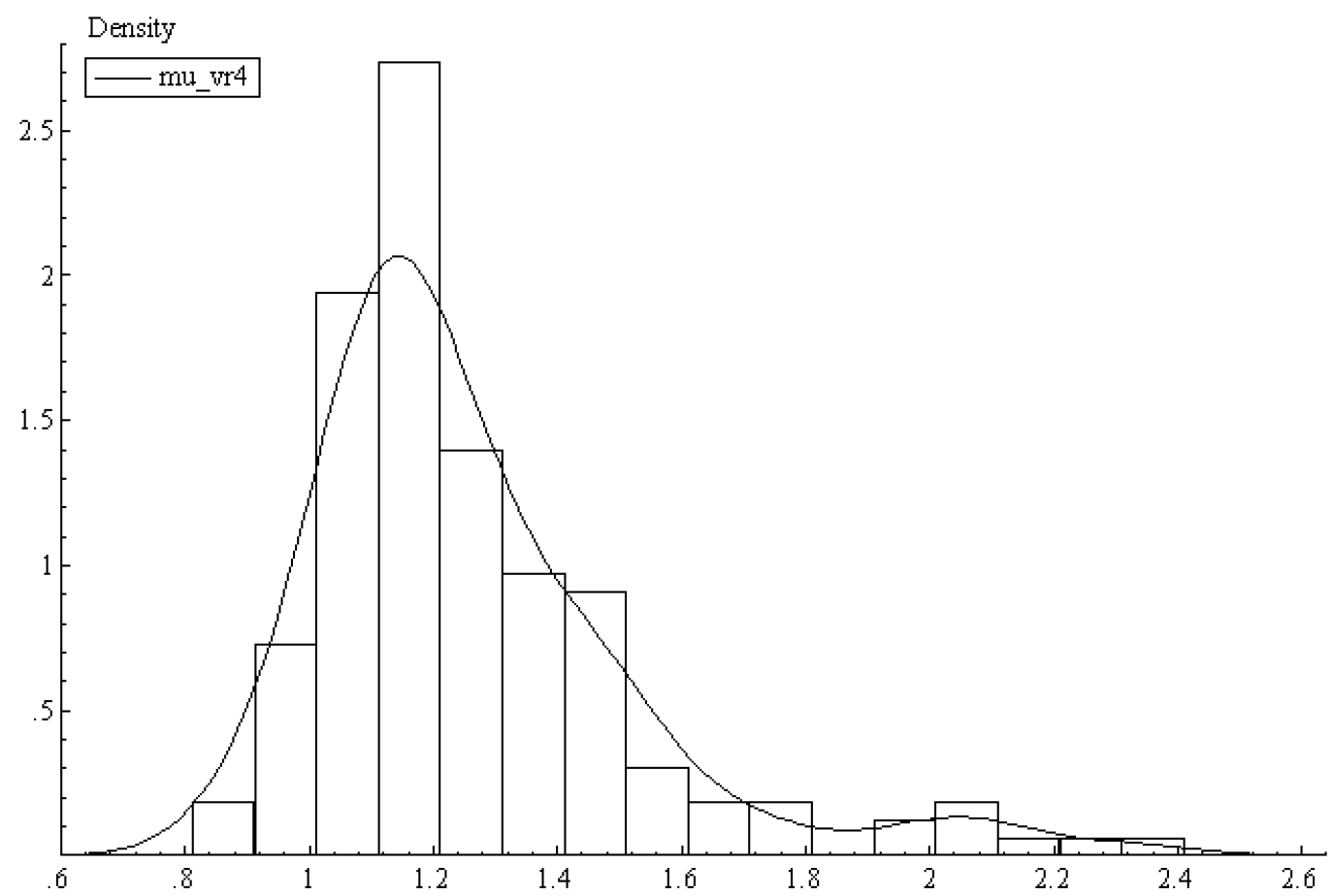

Figure 6. Histogram of markups estimated from value added at NACE4, random effects 


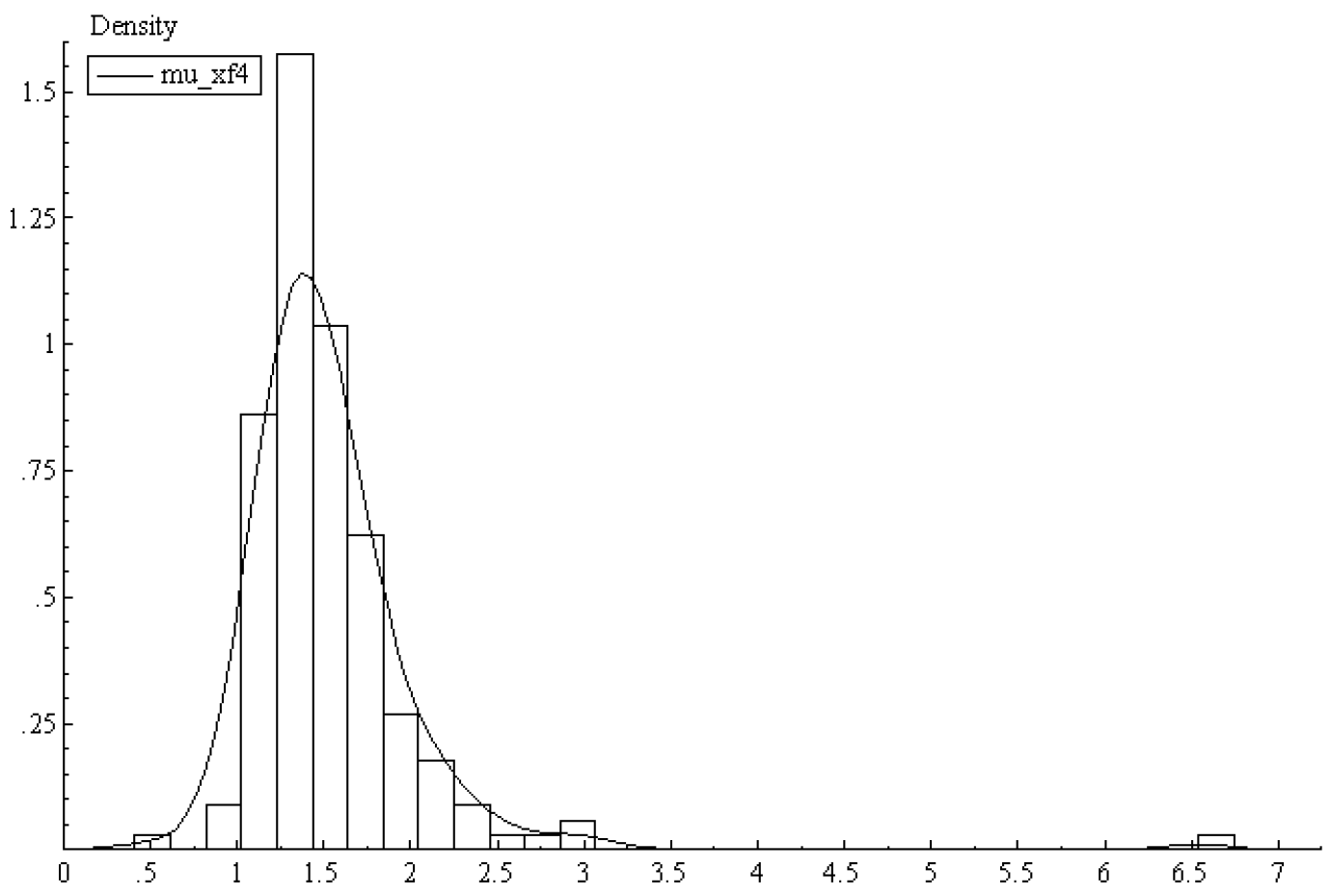

Figure 7. Histogram of markups estimated from sales at NACE4, fixed effects

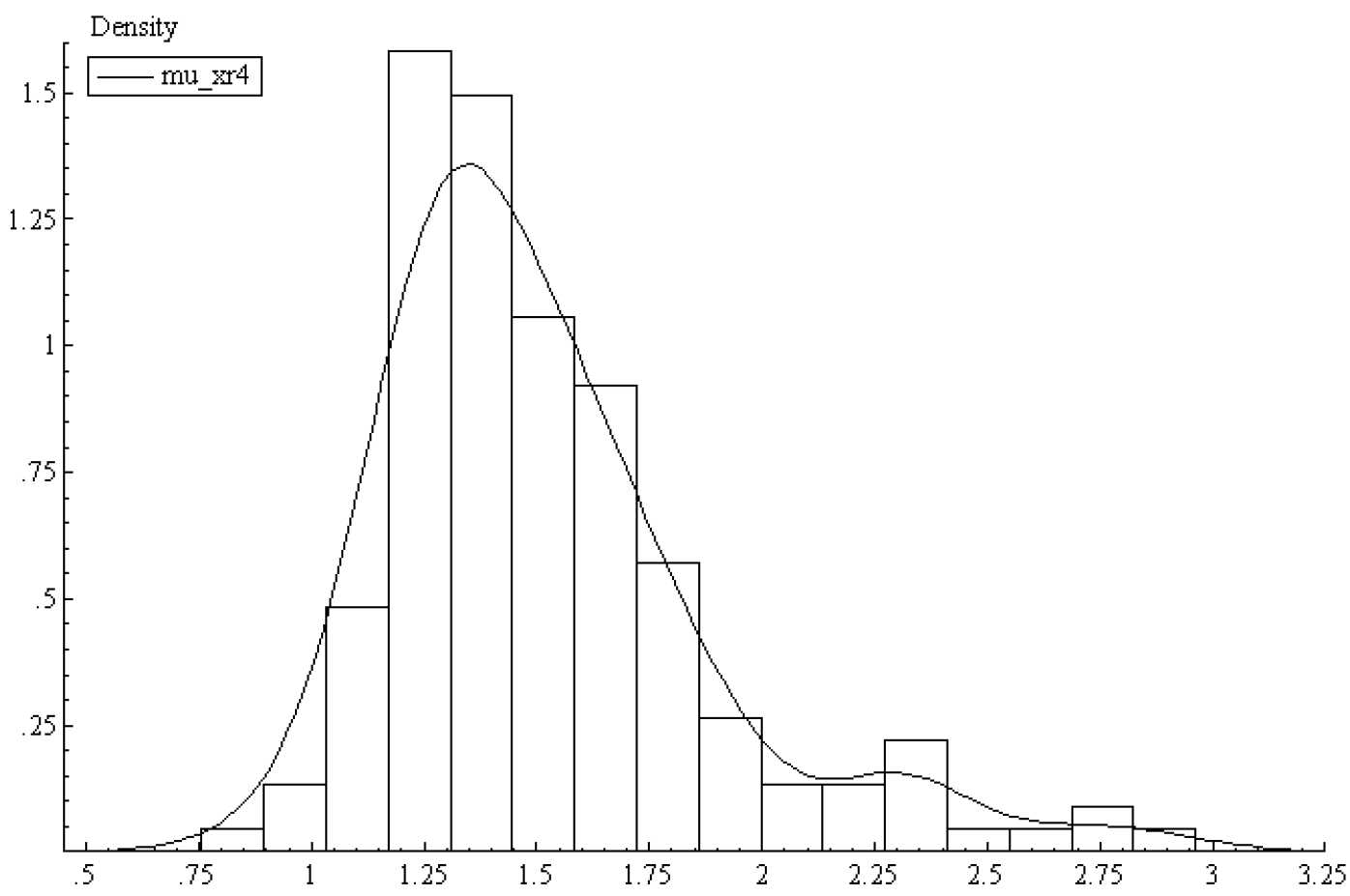

Figure 8. Histogram of markups estimated from sales at NACE4, random effects 
Table 3: Summary of varying coefficient models with concentation variables and value added

\begin{tabular}{|c|c|c|c|c|c|c|c|}
\hline Concentration var and model & constant & $\operatorname{share}_{t-1}$ & impp & conc & joint-F & $\bar{\mu}$ & $\mu \neq 1$ \\
\hline hh for prod, rand.eff., nace 2 & 80.9 & 23.8 & 38.1 & 33.3 & 57.1 & 1.18 & 90.4 \\
\hline hh for prod, fixd.eff., nace 2 & 61.9 & 14.2 & 28.5 & 23.8 & 52.3 & 1.17 & 90.4 \\
\hline dist for prod, rand.eff., nace 2 & 76.1 & 19.0 & 23.8 & 23.8 & 42.8 & 1.29 & 90.4 \\
\hline dist for prod, fixd.eff., nace 2 & 61.9 & 14.2 & 19.0 & 14.2 & 38.1 & 1.03 & 95.2 \\
\hline top3 for prod, rand.eff., nace 2 & 71.4 & 23.8 & 38.1 & 28.5 & 57.1 & 1.21 & 95.2 \\
\hline top3 for prod, fixd.eff., nace 2 & 57.1 & 14.2 & 23.8 & 14.2 & 38.1 & 0.83 & 90.4 \\
\hline rel sd for prod, rand.eff., nace 2 & 71.4 & 28.5 & 23.8 & 52.3 & 61.9 & 1.40 & 85.7 \\
\hline rel sd for prod, fixd.eff., nace 2 & 66.6 & 19.0 & 28.5 & 33.3 & 47.6 & 1.36 & 90.4 \\
\hline hh for emp, rand.eff., nace 2 & 71.4 & 23.8 & 38.1 & 42.8 & 71.4 & 1.41 & 100.0 \\
\hline hh for emp, fixd.eff., nace 2 & 61.9 & 9.5 & 23.8 & 23.8 & 52.3 & 1.23 & 100.0 \\
\hline dist for emp, rand.eff., nace 2 & 71.4 & 23.8 & 28.5 & 38.1 & 52.3 & 1.25 & 100.0 \\
\hline dist for emp, fixd.eff., nace 2 & 61.9 & 14.2 & 19.0 & 23.8 & 38.1 & 1.19 & 100.0 \\
\hline hh for exports, rand.eff., nace 2 & 71.4 & 23.8 & 28.5 & 57.1 & 71.4 & 1.16 & 85.7 \\
\hline hh for exports, fixd.eff., nace 2 & 61.9 & 14.2 & 28.5 & 42.8 & 61.9 & 1.16 & 100.0 \\
\hline 1/No. firms, rand.eff., nace 2 & 76.1 & 23.8 & 38.1 & 33.3 & 66.6 & 1.04 & 76.1 \\
\hline 1/No. firms, fixd.eff., nace 2 & 57.1 & 14.2 & 23.8 & 33.3 & 57.1 & 1.16 & 95.2 \\
\hline hh for prod, rand.eff., nace 3 & 80.9 & 14.2 & 42.8 & 42.8 & 52.3 & 1.18 & 95.2 \\
\hline hh for prod, fixd.eff., nace 3 & 71.4 & 0.0 & 23.8 & 23.8 & 38.1 & 1.20 & 90.4 \\
\hline dist for prod, rand.eff., nace 3 & 70.0 & 10.0 & 20.0 & 30.0 & 50.0 & 1.24 & 95.0 \\
\hline dist for prod, fixd.eff., nace 3 & 65.0 & 0.0 & 15.0 & 25.0 & 40.0 & 1.25 & 100.0 \\
\hline top3 for prod, rand.eff., nace 3 & 76.1 & 14.2 & 33.3 & 38.1 & 42.8 & 1.31 & 80.9 \\
\hline top3 for prod, fixd.eff., nace 3 & 57.1 & 0.0 & 23.8 & 14.2 & 23.8 & 1.29 & 100.0 \\
\hline rel sd for prod, rand.eff., nace 3 & 61.9 & 14.2 & 33.3 & 52.3 & 52.3 & 1.41 & 95.2 \\
\hline rel sd for prod, fixd.eff., nace 3 & 52.3 & 0.0 & 23.8 & 28.5 & 42.8 & 1.49 & 85.7 \\
\hline hh for emp, rand.eff., nace 3 & 80.9 & 14.2 & 47.6 & 42.8 & 61.9 & 1.12 & 90.4 \\
\hline hh for emp, fixd.eff., nace 3 & 66.6 & 0.0 & 23.8 & 14.2 & 38.1 & 1.20 & 100.0 \\
\hline dist for emp, rand.eff., nace 3 & 75.0 & 10.0 & 35.0 & 50.0 & 60.0 & 0.92 & 90.0 \\
\hline dist for emp, fixd.eff., nace 3 & 65.0 & 0.0 & 15.0 & 35.0 & 50.0 & 1.24 & 100.0 \\
\hline hh for exports, rand.eff., nace 3 & 71.4 & 14.2 & 42.8 & 57.1 & 76.1 & 1.49 & 76.1 \\
\hline hh for exports, fixd.eff., nace 3 & 66.6 & 4.7 & 28.5 & 42.8 & 47.6 & 1.24 & 85.7 \\
\hline 1/No. firms, rand.eff., nace 3 & 71.4 & 14.2 & 19.0 & 47.6 & 57.1 & 1.18 & 90.4 \\
\hline 1/No. firms, fixd.eff., nace 3 & 66.6 & 4.7 & 28.5 & 23.8 & 42.8 & 1.07 & 80.9 \\
\hline hh for prod, rand.eff., nace 4 & 58.6 & 20.0 & 45.3 & 42.6 & 62.6 & 1.01 & 77.3 \\
\hline hh for prod, fixd.eff., nace 4 & 38.6 & 13.3 & 29.3 & 29.3 & 46.6 & 0.88 & 73.3 \\
\hline dist for prod, rand.eff., nace 4 & 52.9 & 16.1 & 44.1 & 41.1 & 61.7 & 1.24 & 76.4 \\
\hline dist for prod, fixd.eff., nace 4 & 47.0 & 8.8 & 30.8 & 33.8 & 51.4 & 2.30 & 69.1 \\
\hline top3 for prod, rand.eff., nace 4 & 48.0 & 18.6 & 49.3 & 44.0 & 65.3 & 0.77 & 70.6 \\
\hline top3 for prod, fixd.eff., nace 4 & 33.3 & 12.0 & 36.0 & 30.6 & 50.6 & 0.59 & 74.6 \\
\hline rel sd for prod, rand.eff., nace 4 & 46.6 & 18.6 & 45.3 & 40.0 & 65.3 & -3.81 & 70.6 \\
\hline rel sd for prod, fixd.eff., nace 4 & 37.3 & 17.3 & 32.0 & 26.6 & 50.6 & 0.38 & 76.0 \\
\hline hh for emp, rand.eff., nace 4 & 48.0 & 17.3 & 48.0 & 32.0 & 61.3 & 0.30 & 76.0 \\
\hline hh for emp, fixd.eff., nace 4 & 37.3 & 12.0 & 32.0 & 21.3 & 49.3 & 1.17 & 73.3 \\
\hline dist for emp, rand.eff., nace 4 & 52.9 & 11.7 & 52.9 & 33.8 & 60.2 & 1.27 & 79.4 \\
\hline dist for emp, fixd.eff., nace 4 & 41.1 & 10.2 & 36.7 & 20.5 & 47.0 & 1.39 & 77.9 \\
\hline hh for exports, rand.eff., nace 4 & 53.3 & 16.0 & 42.6 & 40.0 & 62.6 & -0.45 & 80.0 \\
\hline hh for exports, fixd.eff., nace 4 & 44.0 & 10.6 & 28.0 & 34.6 & 50.6 & 1.00 & 74.6 \\
\hline 1/No. firms, rand.eff., nace 4 & 57.3 & 18.6 & 45.3 & 37.3 & 64.0 & 1.30 & 81.3 \\
\hline 1/No. firms, fixd.eff., nace 4 & 46.6 & 13.3 & 28.0 & 29.3 & 54.6 & 0.50 & 80.0 \\
\hline
\end{tabular}

Note: Figures are percentages of tests significant at $5 \%$, except for $\bar{\mu}$ which is the mean of sectoral mark-ups. 
Table 4: Summary of varying coefficient models with concentation variables and sales

\begin{tabular}{|c|c|c|c|c|c|c|c|}
\hline Concentration var and model & constant & share $_{t-1}$ & impp & conc & joint-F & $\bar{\mu}$ & $\mu \neq 1$ \\
\hline hh for prod, rand.eff., nace 2 & 90.4 & 23.8 & 42.8 & 28.5 & 61.9 & 1.47 & 100.0 \\
\hline hh for prod, fixd.eff., nace 2 & 80.9 & 14.2 & 33.3 & 23.8 & 52.3 & 1.51 & 100.0 \\
\hline dist for prod, rand.eff., nace 2 & 90.4 & 23.8 & 38.1 & 33.3 & 61.9 & 1.50 & 95.2 \\
\hline dist for prod, fixd.eff., nace 2 & 80.9 & 14.2 & 23.8 & 23.8 & 42.8 & 1.53 & 95.2 \\
\hline top3 for prod, rand.eff., nace 2 & 80.9 & 28.5 & 38.1 & 28.5 & 61.9 & 1.39 & 85.7 \\
\hline top3 for prod, fixd.eff., nace 2 & 76.1 & 14.2 & 38.1 & 19.0 & 47.6 & 2.28 & 85.7 \\
\hline rel sd for prod, rand.eff., nace 2 & 76.1 & 42.8 & 42.8 & 47.6 & 76.1 & 2.50 & 90.4 \\
\hline rel sd for prod, fixd.eff., nace 2 & 71.4 & 19.0 & 47.6 & 38.1 & 52.3 & 1.43 & 85.7 \\
\hline hh for emp, rand.eff., nace 2 & 85.7 & 19.0 & 42.8 & 33.3 & 61.9 & 1.41 & 95.2 \\
\hline hh for emp, fixd.eff., nace 2 & 80.9 & 14.2 & 42.8 & 9.5 & 42.8 & 1.35 & 95.2 \\
\hline dist for emp, rand.eff., nace 2 & 80.9 & 19.0 & 38.1 & 33.3 & 61.9 & 1.44 & 100.0 \\
\hline dist for emp, fixd.eff., nace 2 & 76.1 & 14.2 & 28.5 & 14.2 & 42.8 & 1.27 & 90.4 \\
\hline hh for exports, rand.eff., nace 2 & 90.4 & 28.5 & 42.8 & 47.6 & 71.4 & 1.10 & 90.4 \\
\hline hh for exports, fixd.eff., nace 2 & 76.1 & 19.0 & 33.3 & 38.1 & 57.1 & 1.28 & 100.0 \\
\hline 1/No. firms, rand.eff., nace 2 & 90.4 & 23.8 & 42.8 & 33.3 & 66.6 & 1.50 & 100.0 \\
\hline 1/No. firms, fixd.eff., nace 2 & 80.9 & 14.2 & 42.8 & 38.1 & 52.3 & 1.47 & 90.4 \\
\hline hh for prod, rand.eff., nace 3 & 76.1 & 14.2 & 23.8 & 38.1 & 52.3 & 1.48 & 100.0 \\
\hline hh for prod, fixd.eff., nace 3 & 76.1 & 14.2 & 19.0 & 19.0 & 38.1 & -0.09 & 95.2 \\
\hline dist for prod, rand.eff., nace 3 & 80.0 & 10.0 & 20.0 & 35.0 & 45.0 & 1.37 & 95.0 \\
\hline dist for prod, fixd.eff., nace 3 & 75.0 & 5.0 & 20.0 & 25.0 & 40.0 & 1.35 & 90.0 \\
\hline top3 for prod, rand.eff., nace 3 & 71.4 & 14.2 & 23.8 & 33.3 & 42.8 & 2.21 & 80.9 \\
\hline top3 for prod, fixd.eff., nace 3 & 71.4 & 14.2 & 28.5 & 19.0 & 33.3 & 1.57 & 85.7 \\
\hline rel sd for prod, rand.eff., nace 3 & 61.9 & 19.0 & 33.3 & 47.6 & 57.1 & 1.38 & 66.6 \\
\hline rel sd for prod, fixd.eff., nace 3 & 71.4 & 9.5 & 19.0 & 38.1 & 47.6 & 2.92 & 76.1 \\
\hline hh for emp, rand.eff., nace 3 & 85.7 & 19.0 & 28.5 & 42.8 & 57.1 & 1.24 & 90.4 \\
\hline hh for emp, fixd.eff., nace 3 & 71.4 & 9.5 & 14.2 & 33.3 & 28.5 & 1.29 & 90.4 \\
\hline dist for emp, rand.eff., nace 3 & 85.0 & 15.0 & 30.0 & 40.0 & 60.0 & 1.46 & 90.0 \\
\hline dist for emp, fixd.eff., nace 3 & 70.0 & 5.0 & 15.0 & 35.0 & 30.0 & 1.47 & 90.0 \\
\hline hh for exports, rand.eff., nace 3 & 66.6 & 19.0 & 28.5 & 38.1 & 47.6 & 1.15 & 95.2 \\
\hline hh for exports, fixd.eff., nace 3 & 66.6 & 14.2 & 14.2 & 33.3 & 38.1 & 1.36 & 85.7 \\
\hline 1/No. firms, rand.eff., nace 3 & 90.4 & 19.0 & 28.5 & 28.5 & 47.6 & 1.48 & 95.2 \\
\hline 1/No. firms, fixd.eff., nace 3 & 71.4 & 9.5 & 14.2 & 23.8 & 33.3 & 1.56 & 95.2 \\
\hline hh for prod, rand.eff., nace 4 & 54.6 & 18.6 & 26.6 & 33.3 & 53.3 & 1.08 & 77.3 \\
\hline hh for prod, fixd.eff., nace 4 & 48.0 & 10.6 & 25.3 & 26.6 & 46.6 & 1.98 & 69.3 \\
\hline dist for prod, rand.eff., nace 4 & 54.4 & 16.1 & 32.3 & 35.2 & 55.8 & 1.04 & 72.0 \\
\hline dist for prod, fixd.eff., nace 4 & 48.5 & 7.3 & 20.5 & 26.4 & 44.1 & 1.98 & 66.1 \\
\hline top3 for prod, rand.eff., nace 4 & 37.3 & 16.0 & 29.3 & 29.3 & 50.6 & 2.00 & 64.0 \\
\hline top3 for prod, fixd.eff., nace 4 & 29.3 & 10.6 & 20.0 & 22.6 & 41.3 & -0.31 & 76.0 \\
\hline rel sd for prod, rand.eff., nace 4 & 44.0 & 17.3 & 30.6 & 34.6 & 56.0 & 1.47 & 74.6 \\
\hline rel sd for prod, fixd.eff., nace 4 & 37.3 & 9.3 & 25.3 & 29.3 & 46.6 & 2.14 & 70.6 \\
\hline hh for emp, rand.eff., nace 4 & 58.6 & 17.3 & 30.6 & 22.6 & 52.0 & 2.35 & 74.6 \\
\hline hh for emp, fixd.eff., nace 4 & 44.0 & 10.6 & 26.6 & 16.0 & 38.6 & 0.38 & 69.3 \\
\hline dist for emp, rand.eff., nace 4 & 57.3 & 16.1 & 29.4 & 26.4 & 51.4 & 0.61 & 79.4 \\
\hline dist for emp, fixd.eff., nace 4 & 41.1 & 8.8 & 22.0 & 16.1 & 35.2 & 0.14 & 80.8 \\
\hline hh for exports, rand.eff., nace 4 & 49.3 & 21.3 & 36.0 & 22.6 & 50.6 & 1.92 & 77.3 \\
\hline hh for exports, fixd.eff., nace 4 & 42.6 & 10.6 & 25.3 & 22.6 & 45.3 & 1.38 & 74.6 \\
\hline 1/No. firms, rand.eff., nace 4 & 62.6 & 16.0 & 30.6 & 25.3 & 46.6 & 1.80 & 78.6 \\
\hline 1/No. firms, fixd.eff., nace 4 & 53.3 & 9.3 & 26.6 & 24.0 & 40.0 & 2.19 & 72.0 \\
\hline
\end{tabular}

Note: Figures are percentages of tests significant at $5 \%$, except for $\bar{\mu}$ which is the mean of sectoral mark-ups. 
Table 5: Estimated markup, varying coefficients, random effects

\begin{tabular}{|c|c|c|c|c|c|c|c|}
\hline Nace & constant & dom.priv. & foreign & rel sd of sales & $\mathrm{R}^{2}$ & Wald-test & $\bar{\mu}$ \\
\hline 15 & $0.13 * *$ & $-0.06 * *$ & $-0.08 * *$ & 0.02 & 0.24 & $26.82 * *$ & $1.13 * *$ \\
\hline 17 & $0.09 * *$ & $-0.09 * *$ & $-0.09 * *$ & $0.02 * *$ & 0.23 & $24.76 * *$ & $1.07 * *$ \\
\hline 18 & $0.17 * *$ & -0.01 & -0.03 & $-0.02 * *$ & 0.16 & $14.99 * *$ & $1.17 * *$ \\
\hline 19 & 0.01 & -0.04 & 0.03 & 0.03 & 0.26 & 6.42 & $1.05 * *$ \\
\hline 20 & $0.22 * *$ & $-0.16 * *$ & -0.02 & -0.02 & 0.20 & $10.31 *$ & $1.24 * *$ \\
\hline 21 & $0.26 * *$ & 0.03 & $0.17 * *$ & $-0.04 *$ & 0.40 & $27.45 * *$ & $1.47 * *$ \\
\hline 22 & $0.19 * *$ & -0.05 & $0.08 * *$ & 0.01 & 0.44 & $13.76 * *$ & $1.26 * *$ \\
\hline 24 & 0.08 & -0.03 & 0.01 & $0.04 *$ & 0.25 & 5.91 & $1.10 * *$ \\
\hline 25 & $0.74 * *$ & -0.05 & -0.01 & $-0.15 * *$ & 0.52 & $61.46 * *$ & -1.25 \\
\hline 26 & $0.33 * *$ & $-0.05 *$ & 0.05 & $-0.07 * *$ & 0.35 & $45.41 * *$ & $1.47 * *$ \\
\hline 27 & -0.01 & -0.01 & 0.08 & $0.05 * *$ & 0.27 & $15.99 * *$ & $1.04 * *$ \\
\hline 28 & $0.25 * *$ & $-0.09 * *$ & 0.03 & $-0.03 * *$ & 0.29 & $51.17 * *$ & $1.30 * *$ \\
\hline 29 & $0.21 * *$ & $-0.11 * *$ & -0.04 & -0.01 & 0.28 & $21.62 * *$ & $1.22 * *$ \\
\hline 30 & $0.50 * *$ & $-0.67 * *$ & $-0.40 * *$ & 0.03 & 0.66 & $25.16 * *$ & $1.48 * *$ \\
\hline 31 & $0.50 * *$ & -0.05 & $0.12 * *$ & $-0.06 * *$ & 0.57 & $134.16 * *$ & $1.88 * *$ \\
\hline 32 & $-0.31 * *$ & $0.15 * *$ & $0.22 * *$ & $0.10 * *$ & 0.65 & $102.81 * *$ & 0.70 \\
\hline 33 & $0.33 *$ & $-0.08 * *$ & 0.01 & -0.04 & 0.33 & $9.53 *$ & $1.44 * *$ \\
\hline 34 & $0.23 *$ & $-0.22 * *$ & -0.05 & 0.00 & 0.35 & $29.43 * *$ & $1.21 * *$ \\
\hline 35 & -0.06 & 0.07 & $0.21 *$ & 0.04 & 0.13 & 6.15 & 1.01 \\
\hline 36 & 0.04 & $0.15 * *$ & 0.01 & 0.02 & 0.38 & $40.81 * *$ & $1.09 * *$ \\
\hline 37 & 0.53 & 0.22 & $-0.34 * *$ & -0.18 & 0.40 & $13.66 * *$ & $3.01 *$ \\
\hline
\end{tabular}




\section{DAVIDSON INSTITUTE WORKING PAPER SERIES - Most Recent Papers}

The entire Working Paper Series may be downloaded free of charge at: www.wdi.bus.umich.edu

CURRENT AS OF 11/30/01

\begin{tabular}{|c|c|c|}
\hline Publication & Authors & Date \\
\hline No. 411: Mark-ups in Hungarian Corporate Sector & László Halpern and Gábor Körösi & Aug. 2001 \\
\hline No. 410: Economic Development, Legality, and the Transplant Effect & $\begin{array}{l}\text { Daniel Berkowitz, Katarina } \\
\text { Pistor, Jean-Francois Richard }\end{array}$ & Sept. 2001 \\
\hline No. 409: Development Strategy, Viability, and Economic Convergence & Justin Yifu Lin & Oct. 2001 \\
\hline No. 408: Labor Supply, Informal Economy and Russian Transition & Maxim Bouev & May 2001 \\
\hline No. 407: Corporate Governance in China: Then and Now & Cindy Schipani and Liu Junhai & Nov. 2001 \\
\hline No. 406: Entrepreneurship and Post-Socialist Growth & $\begin{array}{l}\text { Daniel Berkowitz and David N. } \\
\text { DeJong }\end{array}$ & Oct. 2001 \\
\hline $\begin{array}{l}\text { No. } 405 \text { Forthcoming in: European Economic Review, "Policy Reform } \\
\text { and Growth in Post-Soviet Russia." }\end{array}$ & $\begin{array}{l}\text { Daniel Berkowitz and David N. } \\
\text { DeJong }\end{array}$ & Oct. 2001 \\
\hline $\begin{array}{l}\text { No. 404: Social Policies and Structures: Institutional Frictions and Traps } \\
\text { in the Czech Republic after } 1989\end{array}$ & Jiří Večerník & Nov. 2001 \\
\hline $\begin{array}{l}\text { No. 403: Investment, Efficiency, and Credit Rationing: Evidence from } \\
\text { Hungarian Panel Data }\end{array}$ & Mathilde Maurel & Nov. 2001 \\
\hline $\begin{array}{l}\text { No. 402: Subduing High Inflation in Romania. How to Better Monetary } \\
\text { and Exchange Rate Mechanisms? }\end{array}$ & $\begin{array}{l}\text { Daniel Daianu and Radu } \\
\text { Vranceanu }\end{array}$ & Aug. 2001 \\
\hline $\begin{array}{l}\text { No. 401: The Gender Wage Gap in Bulgaria: A Semiparametric } \\
\text { Estimation of Discrimination }\end{array}$ & Dean Jolliffe & July 2001 \\
\hline $\begin{array}{l}\text { No. 400: Do External Auditors Perform a Corporate Governance Role in } \\
\text { Emerging Markets? Evidence from East Asia }\end{array}$ & Joseph P. H. Fan and T.J. Wong & Oct. 2001 \\
\hline $\begin{array}{l}\text { No. 399: Financial Conditions and Investment during the Transition: } \\
\text { Evidence from Czech Firms }\end{array}$ & Lubomír Lízal and Jan Svejnar & Oct. 2001 \\
\hline $\begin{array}{l}\text { No. 398: Accessible Pareto-Improvements: Using Market Information to } \\
\text { Reform Inefficiencies }\end{array}$ & Michael Mandler & May 2001 \\
\hline No. 397: The Making of an Integrated National Grain Market in China & $\mathrm{W}$ & Oct. 2001 \\
\hline No. 396: Corruption and Resource Allocation: Evidence from China & Wei Li & June 2001 \\
\hline $\begin{array}{l}\text { No. 395: Government Shareholding and the Value of China's Modern } \\
\text { Firms }\end{array}$ & Lihui Tian & Apr. 2001 \\
\hline No. 394: Labor Hoarding in Russia: Where Does it Come from? & $\begin{array}{l}\text { Rouslan Koumakhov and Boris } \\
\text { Najman }\end{array}$ & June 2000 \\
\hline $\begin{array}{l}\text { No. 393: Ownership Structure, Corporate Governance, And Firm Value: } \\
\text { Evidence from the East Asian Financial Crisis }\end{array}$ & Michael Lemmon and Karl Lins & Apr. 2001 \\
\hline No. 392: Marshall and Labour Demand in Russia: Going Back to Basics & $\begin{array}{l}\text { Jozef Konings and Hartmut } \\
\text { Lehmann }\end{array}$ & Aug. 2001 \\
\hline No. 391: Economic Transition and Elections in Poland & $\begin{array}{l}\text { John E. Jackson, Jacek Klich, and } \\
\text { Krystyna Poznańska }\end{array}$ & June 2001 \\
\hline $\begin{array}{l}\text { No. 390: Effects of Bank Insolvency and Strategic Uncertainty on } \\
\text { Corporate Restructuring in Transition Economies }\end{array}$ & Christa Hainz & Aug. 2001 \\
\hline No. 389: Mark-Up Pricing In Bulgarian Manufacturing & $\begin{array}{l}\text { Rumen Dobrinsky, Boyko } \\
\text { Nikolov, and Nikolay Markov }\end{array}$ & June 2001 \\
\hline $\begin{array}{l}\text { No. 388: Globalization and Firms' Financing Choices: } \\
\text { Evidence from Emerging Economies }\end{array}$ & $\begin{array}{l}\text { Sergio Schmukler and Esteban } \\
\text { Vesperoni }\end{array}$ & May 2001 \\
\hline $\begin{array}{l}\text { No. 387: The Distributional Impacts of Indonesia's Financial Crisis on } \\
\text { Household Welfare: A "Rapid Response" Methodology }\end{array}$ & $\begin{array}{l}\text { Jed Friedman and James } \\
\text { Levinsohn }\end{array}$ & Sept. 2001 \\
\hline $\begin{array}{l}\text { No. 386a: Corporate Financial Policies and Performance Around } \\
\text { Currency Crises }\end{array}$ & $\begin{array}{l}\text { Arturo Bris, Yrjö Koskinen, and } \\
\text { Vicente Pons }\end{array}$ & Oct. 2001 \\
\hline No. 385: Ownership and Productive Efficiency: Evidence from E & Derek C. Jones and Niels Mygind & Aug. 2001 \\
\hline
\end{tabular}

